Sustainability, Agri, Food and Environmental Research, (ISSN: 0719-3726), 9(3), 2021: 347-368

http://dx.doi.org/10.7770/safer-V0N0-art2316

\title{
Biochemical Studies on edible oysters Crassostrea madrasensis and Saccostrea cucullata.
}

\section{Biochemical Studies on edible oysters Crassostrea madrasensis and Saccostrea cucullata.}

\author{
P.Paul , J. Siva, A.Priya and C. Stella,* \\ School of marine studies, Department of Oceanography and coastal area studies, Alagappa \\ University, Karaikudi, 630003, India. \\ pauljai4@gmail.com; sivaocean1107@gmail.com; priya_adikesavan@yahoo.co.in \\ * Author for correspondence, email: stella2004@rediffmail.com
}

\section{ABSTRACT}

In general, changes in biochemical components are closely linked to the state of sexual maturity of the mollusks and to energy supply, either directly from ingested food or from previously stored reserves. Carbohydrates are considered to be the main energy source in adult marine bivalves and are important for gamete formation and maintenance of adult condition during periods of nutritive stress or in winter. Many studies have related changes in the biochemical composition of bivalves with the reproductive cycle mostly in the natural environment. Energy storage and biochemical cycle are closely related to reproductive activity in marine bivalves. The present study indicates that major biochemical constituents in oyster Crassostrea madrasensis and Saccostrea cucullate are significantly influenced by environment condition such as quantity of food availability, temperature and salinity. The high contents of lipids, proteins, carbohydrates, and water content values, during summer are indicating this season as the best for harvesting this particular oyster species and the statistical analysis of the biochemical composition of the tissue sample of the oyster revealed positive correlation in both species of oyster Crassostrea madrasensis and Saccostrea cucullata. The strong Positive Correlation were observed in between the two stations and the highest value of protein, carbohydrate and lipids were observed in Crassostrea madrasensis rock and creek when it compare to Saccostrea cucullata.

Keywords: Protein, Carbohydrate, Lipid , Crassostrea madrasensis, Saccostrea cucullata, oysters 
Sustainability, Agri, Food and Environmental Research, (ISSN: 0719-3726), 9(3), 2021: 347-368 http://dx.doi.org/10.7770/safer-V0N0-art2316

\section{RESUMEN}

En general, los cambios en los componentes bioquímicos están íntimamente ligados al estado de madurez sexual de los moluscos y al aporte energético, ya sea directamente de los alimentos ingeridos o de las reservas almacenadas previamente. Se considera que los carbohidratos son la principal fuente de energía en los bivalvos marinos adultos y son importantes para la formación de gametos y el mantenimiento de la condición adulta durante períodos de estrés nutricional o en invierno. Muchos estudios han relacionado los cambios en la composición bioquímica de los bivalvos con el ciclo reproductivo principalmente en el medio ambiente natural. El almacenamiento de energía y el ciclo bioquímico están estrechamente relacionados con la actividad reproductiva de los bivalvos marinos. El presente estudio indica que los principales componentes bioquímicos de la ostra Crassostrea madrasensis y Saccostrea cucullate están significativamente influenciados por las condiciones ambientales, como la cantidad de alimentos disponibles, la temperatura y la salinidad. Los altos contenidos de lípidos, proteínas, carbohidratos y valores de contenido de agua, durante el verano, están indicando esta temporada como la mejor para la recolección de esta especie de ostra en particular y el análisis estadístico de la composición bioquímica de la muestra de tejido de la ostra reveló correlación positiva en ambas especies de ostras Crassostrea madrasensis y Saccostrea cucullata. Se observó una fuerte correlación positiva entre las dos estaciones y el valor más alto de proteínas, carbohidratos y lípidos se observó en la roca y el arroyo Crassostrea madrasensis en comparación con Saccostrea cucullata.

Palabras clave: Proteina, Carbohidratos, Lípidos, Crassostrea madrasensis, Saccostrea cucullata, oysters

\section{INTRODUCTION}

Bivalve mollusks like oysters, mussels, clams, scallops etc are highly esteemed delicious sea foods and are considered as next in important to fishes and prawns. Inter annual or local differences in the energy storage cycle and reproduction of marine bivalves are often associated with changes in environmental conditions, particularly the amount of food in the water column (Newell, 1988; Rodhouse et al., 1984; Bricelj et al., 1987; Navarro et al., 1989; Kang et al., 2000). In India, various studies on the biochemical composition of bivalves have been carried out by Venkataraman and Chari (1951) on Meretrix casta and Crassostrea madrasensis, In western waters biochemical studies have been carried out by Park et al., (2001) in ark shell Scapharca broughtonii. Many studies have related changes in the 
Sustainability, Agri, Food and Environmental Research, (ISSN: 0719-3726), 9(3), 2021: 347-368 http://dx.doi.org/10.7770/safer-V0N0-art2316

biochemical composition of bivalves with the reproductive cycle mostly in the natural environment. Energy storage and biochemical cycle are closely related to reproductive activity in marine bivalves (Giese, 1969; Bayne,1976; Ojea et al., 2004). Beninger and Lucas (1984) and Bressan and Martin (1985) studied the close relationship between biochemical composition and reproductive cycle of Mytilus species. Widdows and Bayne (1971) observed high contents of glycogen in Mytilus edulis during summer. The oyster Crassostrea madrasensis and mussel Perna viridis are distributed at several places along the east and southwest coasts of India and has good economic potential and nutritional quality.

In general, changes in biochemical components are closely linked to the state of sexual maturity of the mollusks and to energy supply, either directly from ingested food or from previously stored reserves (Sastry, 1979; Navarro et al., 1989). Carbohydrate, particularly glycogen are considered to be the main energy source in adult marine bivalves and are important for gamete formation and maintenance of adult condition during periods of nutritive stress or in winter (De Zwaan and Zandee, 1984).Beninger, (1982) studied the variations in Carbohydrate content show an inverse relationship with the state of gonad maturity. According to Beninger and Lucas (1984) and Holland, (1978) studied the lipids form a part of the reserves during periods of nutritional deficiency and are an important of bivalve Oocytes. Salaskar and Nayak (2011) studied the nutritional quality of bivalves in Crassostrea madrasensis and Perna viridis in the kali estuary. Martin et al., (2003) reported the variation in gross biochemical composition energy value and condition index of venerid clams. Albentosa et al.,(2007) studied the response of two species of clams to starvation of physiological and biochemical parameters. Dridi et al., (2007) studied the seasonal variation in weight and biochemical composition of the Pacific oyster. Kang et al., (2007) studied the condition, reproductive activity and gross biochemical composition of the manila clams. Albentosa et al., (2003) studied the absorption of biochemical components and feeding behavior with natural and carbohydrate rich diets in Ruditapes decussates.

Marine molluscs provide highly nutritious food for human consumption as they store large quantities of glycogen and fat (Nagabhushanam and Bidarkar, 1978; Kumari and Nair, 1988). Oysters and other bivalves form low-cost subsistence food of the coastal people, especially the local fishermen communities (Stephen, 1980a). The nutritive value of molluscs is governed by the various ecological and environmental parameters in ambience (Ruiz et al., 1992).The understanding of biochemical composition in various marine organisms plays a very important role in providing their nutritive value (Qasim et al., 1977; Parulekar et al., 1982; Mohan and Kalyani, 1989a,b). The biochemical composition has been reported to be 
Sustainability, Agri, Food and Environmental Research, (ISSN: 0719-3726), 9(3), 2021: 347-368 http://dx.doi.org/10.7770/safer-V0N0-art2316

influenced by the salinity concentration in the surrounding water column (Durve and Bal, 1961; Saraswathy and Nair, 1969; Stephen, 1980b).

The biochemical composition is the yardstick to measure and assess the nutritional quality of food sources. Biochemical compositions vary during different stages in species and it is more appropriate to assess the biochemical composition of seafood. Oysters from mangrove influenced ambiance represent major source of potential nutrition for human consumption. Therefore, it is more desirable to understand the most important facts relating to its nutritive value by determining the normal fluctuations in biochemical composition of the species. The present work was, undertaken to get an insight on the seasonal variation of water content (moisture), proteins, carbohydrates, and lipids levels in the flesh of the edible oyster, Crassostrea madrasensis and Saccostrea cucullata which is growing in association with mangroves habitats from rock and creek of Karankadu.

\section{MATERIALS AND METHODS}

Collection of specimens: Oysters were collected every month from the study area and brought to the laboratory. They were kept in fiber glass trough with filtered seawater prior to analysis so as to allow them to empty their gut contents. The maximum size of animals were selected for biochemical studies. The animals were washed with tap waters. The whole body tissue was dried in an oven at a constant temperature of $60^{\circ} \mathrm{C}$ for 24 hours. The dried material was powered and sieved using a bolting silk cloth. The powered meat was used for further analysis. Further, the animals were opened and their meat was weighed separately. The dried components were bought to constant weight, after which the biochemical components were estimated. Five estimation were made in each case and the average was taken in to consideration.

Water Contents: Water (moisture) contents of oyster species under investigation were determined gravimetrically, by calculating the difference between the wet weight of the sample and its weight after drying, and the results were expressed in percentage. The formula used for calculation was as:

Wet weight of flesh -dry weight of flesh

Water content $(\%)=100$ 
Sustainability, Agri, Food and Environmental Research, (ISSN: 0719-3726), 9(3), 2021: 347-368 http://dx.doi.org/10.7770/safer-V0N0-art2316

Protein: Protein was estimated by Biuret method as modified by Raymount et al., (1964). 20mg of dried material was taken and homogenized in a hand homogenizer with 1 $\mathrm{ml}$ of glass distilled water. $2 \mathrm{ml}$ of biuret reagent was added two times and the tissues grinder was cleaned before transferred to the centrifuge tube. After 30 minutes, this sample was centrifuged for ten minutes and the supernatant fluid was transferred in to another tube. Then the calorimetric reading of the supernatant fluid was measured using UV-VIS Double beam Spectrophotometer (UVD-2960) at the wave length of 540nm against the blank reading and then the percentage of protein was calculated.

Carbohydrates: For the estimation of the total carbohydrate content, the procedure of Dubios et al., (1956) was followed. $20 \mathrm{mg}$ of dried tissue powder was taken and to this $1.0 \mathrm{ml}$ of the glass distilled water followed by $1.0 \mathrm{ml}$ of $4 \%$ phenol solution and $5 \mathrm{ml}$ of concentrated sulphuric acid were added. After 30 minutes, calorimetric reading was taken in UV-VIS Double beam Spectrophotometer (UVD-2960) at the wave length of 490nm against the blank reading and then the percentage of carbohydrate was calculated.

Lipids: The chloroform methanol extraction procedure of Folch et al., (1957) was adapted for extracting lipid from the tissue. About $400 \mathrm{mg}$ of powdered tissue was taken in a $10 \mathrm{ml}$ beaker and to this $5 \mathrm{ml}$ of Chloroform-Methanol mixture (3:1) was added. The mouth of the beaker was covered by aluminium foil and kept as such overnight for lipid extraction. This extract was filtered using micro filter. The filtrate was taken in a pre weighed beaker and evaporated in hot air over. The beaker was reweighed with lipid. The difference in weight was taken as total fat content and the percentage was calculated accordingly.

\section{RESULTS}

Water Content: Crassostrea madrasensis in rock area, the water content of the whole animal were fluctuated between $73 \%$ - 90\%. The maximum water content value was recorded in October (90\%) and the minimum valve was recorded in May (50.4\%). In creek area, higher percentage of water content was recorded $88 \%$ during November and the lower percentage of water content valves was recorded $71 \%$ during June. In whole animal, lower values were observed during summer and the higher values were observed during Monsoon (Fig 1). In Saccostrea cucullata in rock area, the water content in the whole animal were fluctuated between $71 \%$ to $88 \%$. The maximum water content value was recorded in October $(88 \%)$ and the minimum valve was recoded in May (71\%). In creek area, higher percentage of water content was recorded $(83 \%)$, during October and the lower percentage of water content 
Sustainability, Agri, Food and Environmental Research, (ISSN: 0719-3726), 9(3), 2021: 347-368 http://dx.doi.org/10.7770/safer-V0N0-art2316

valves was recorded $72 \%$ during June. In whole animal, lower values were observed during summer and the higher values were observed during Monsoon (Table 1 and 2).

Protein: Crassostrea madrasensis in rock area, the protein content in the whole animal were fluctuated between $31.3 \%-68.5 \%$. The maximum protein content value was recorded in June (68.5\%) and the minimum value was recorded in October (31.3\%). In creek area, higher percentage of protein content was recorded 64\% during June and the lower percentage of protein content values was recorded 30\% during December. In whole animal, lower values were observed during monsoon and the higher values were observed during summer (Fig 2). In Saccostrea cucullatain rock area, the protein content in the whole animal were fluctuated between $32.8 \%$ - 65.8\%. The maximum water protein value was recorded in April (65.8\%) and the minimum value was recorded in December (32.8\%). In creek area, higher percentage of protein content was recorded (62.2\%), during April and the lower percentage of protein content values was recorded (30\%) during November. In whole animal, lower values were observed during monsoon and the higher values were observed during summer (Table 3 and 4).

Table 1. Regression Analysis of Crassostrea madrasensis and Saccostrea cucullata (Water content)

\begin{tabular}{lccccc}
\hline \multicolumn{1}{c}{ Category } & $\mathrm{n}$ & $\mathrm{A}$ & $\mathrm{b}$ & $\mathrm{r}$ & $\mathrm{P}$ \\
\hline Crassostrea madrasensis & 12 & $32.09 \pm 11.53$ & $0.5481 \pm 0.1430$ & 0.771422 & 0.0033 \\
Saccostrea cucullate & 12 & $26.27 \pm 13.63$ & $0.6200 \pm 0.1722$ & 0.7514 & 0.0048 \\
\hline
\end{tabular}

Table.2. Analysis of Variance of Crassostrea madrasensis and Saccostrea cucullata (Water content)

\begin{tabular}{lccccc}
\hline \multicolumn{5}{c}{ Crassostrea madrasensis } & - Moisture \\
\hline Regression & Df & SS & MS & F & Significance F \\
Residual & 1 & 135.4826 & 135.4826 & 14.69696 & 0.003299 \\
Total & 10 & 92.18407 & 9.218407 & & \\
& 11 & 227.6667 & & & \\
& & \multicolumn{4}{c}{ Saccostrea cucullata Moisture } \\
Regression & Df & SS & MS & F & Significance F \\
Residual & 1 & 115.32 & 115.32 & 12.9675 & 0.00484 \\
Total & 10 & 88.93 & 8.893 & & \\
\hline
\end{tabular}


Sustainability, Agri, Food and Environmental Research, (ISSN: 0719-3726), 9(3), 2021: 347-368 http://dx.doi.org/10.7770/safer-V0N0-art2316

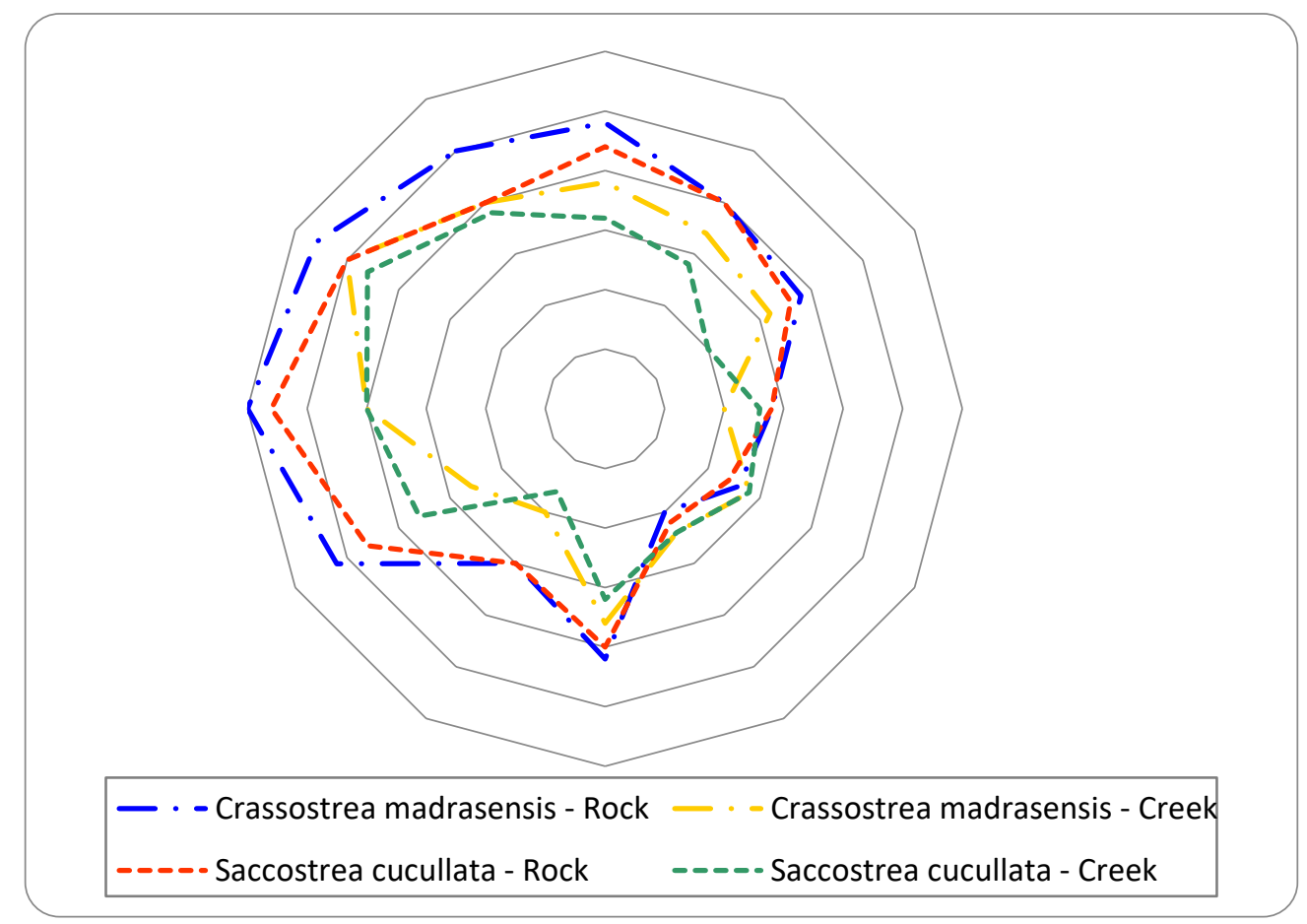

Fig.1. Water content of Crassostrea madrasensis and Saccostrea cucullata

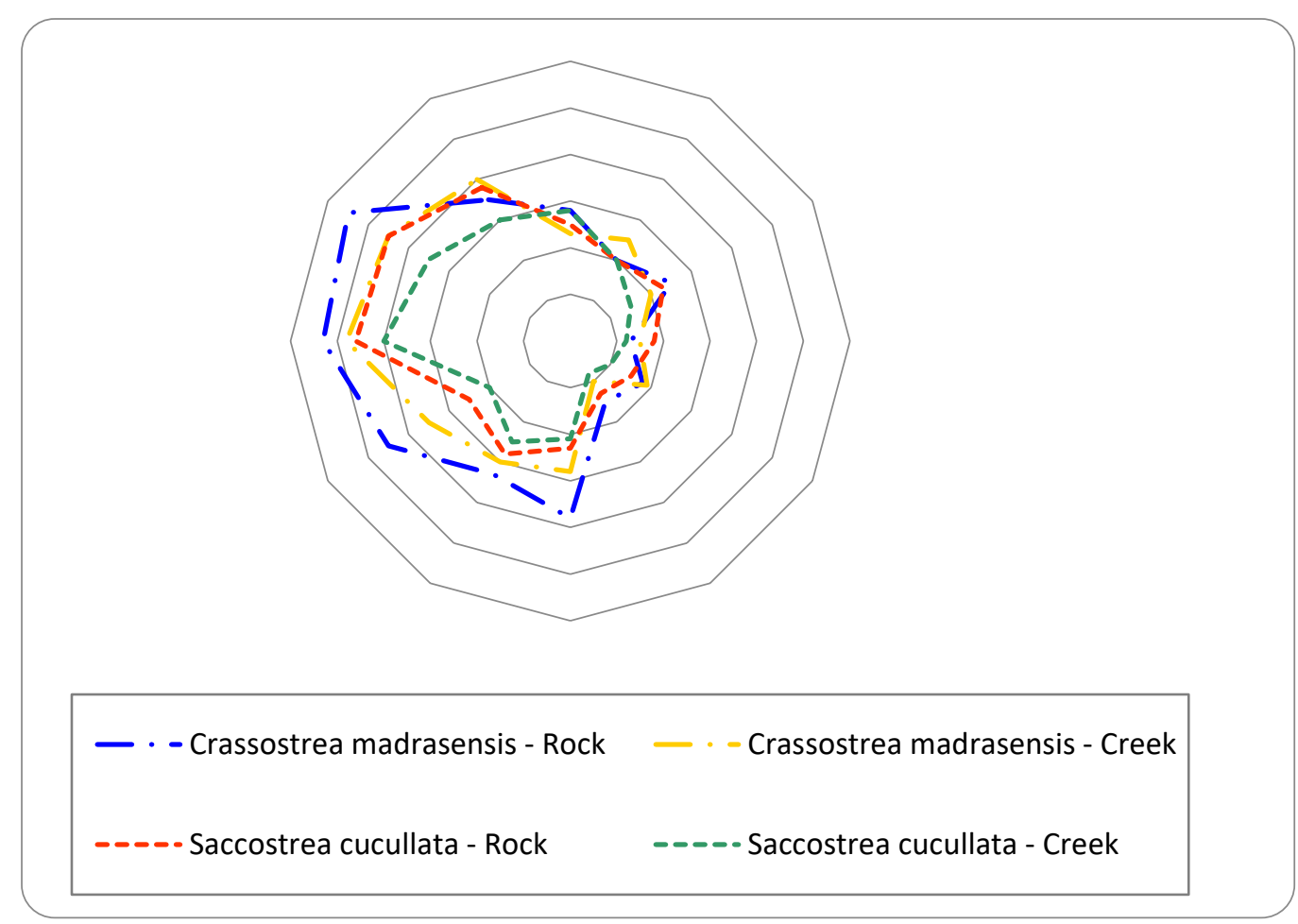

Fig. 2. Protein of Crassostrea madrasensis and Saccostrea cucullata 
Sustainability, Agri, Food and Environmental Research, (ISSN: 0719-3726), 9(3), 2021: 347-368 http://dx.doi.org/10.7770/safer-V0N0-art2316

Table 3. Regression Analysis of Protein content in Crassostrea madrasensis and Saccostrea cucullata

\begin{tabular}{lccccc}
\hline \multicolumn{1}{c}{ Category } & $\mathrm{n}$ & $\mathrm{A}$ & $\mathrm{b}$ & $\mathrm{r}$ & $\mathrm{P}$ \\
\hline Crassostrea madrasensis & 12 & $1.909 \pm 2.858$ & $0.9228 \pm .05490$ & 0.982696 & $<0.0001$ \\
Saccostrea cucullate & 12 & $-0.1644 \pm 2.948$ & $0.9476 \pm 0.05592$ & 0.991368 & $<0.0001$ \\
\hline
\end{tabular}

Table 4. Analysis of Variance for Protein content of Crassostrea madrasensis and Saccostrea cucullata

\begin{tabular}{lccccc}
\hline \multicolumn{5}{c}{ Crassostrea madrasensis Protein Content } \\
\hline Regression & 1 & 1474.85 & 1474.85 & 253.3206 & Significance F \\
Residual & 9 & 52.39863 & 5.82207 & & $6.73 \mathrm{E}-08$ \\
Total & 10 & 1527.249 & & & \\
& & \multicolumn{5}{c}{ Saccostrea cucullata Protein content } & \\
& Df & SS & MS & F & Significance F \\
& 1 & 1094.446 & 1094.446 & 514.5596 & $2.98 \mathrm{E}-09$ \\
Residual & 9 & 19.14262 & 2.126958 & & \\
Total & 10 & 1113.589 & & & \\
\hline
\end{tabular}

Carbohydrate: Crassostrea madrasensis in rock area, the carbohydrate content in the whole animal were fluctuated between $26.8 \%-14 \%$. The maximum carbohydrate content value was recorded in April (26.8\%) and the minimum value was recorded in November $(14 \%)$. In creek are, higher percentage of carbohydrate content was recorded (24\%) during May and the lower percentage of carbohydrate content values was recorded (14\%) during October. In whole animal, lower values were observed during Monsoon and the higher values were observed during summer (Fig 3). In Saccostrea cucullata in rock area, the carbohydrate content in the whole animal were fluctuated between $13.5 \%$ to $25 \%$. The maximum water value was recorded in May (25\%) and the minimum valve was recorded in December (13.5\%). In creek area, higher percentage of carbohydrate content was recorded (24\%), during May and the lower percentage of carbohydrate content valves was recorded (13.6\%) during December. In whole animal, lower values were observed during Monsoon and the higher values were observed during summer (Table 5 and 6). 
Sustainability, Agri, Food and Environmental Research, (ISSN: 0719-3726), 9(3), 2021: 347-368 http://dx.doi.org/10.7770/safer-V0N0-art2316

Table 5. Regression Analysis of Carbohydrate content in Crassostrea madrasensis and Saccostrea cucullata

\begin{tabular}{lccccc}
\hline \multicolumn{1}{c}{ Category } & $\mathrm{n}$ & $\mathrm{A}$ & $\mathrm{B}$ & $\mathrm{r}$ & $\mathrm{P}$ \\
\hline Crassostrea madrasensis & 12 & $2.690 \pm 1.418$ & $0.8242 \pm 0.07834$ & 0.957681 & $<0.0001$ \\
Saccostrea cucullate & 12 & $0.9550 \pm 1.595$ & $0.9426 \pm 0.09238$ & 0.955175 & $<0.0001$ \\
\hline
\end{tabular}

Table 6 Analysis of Variance of Carbohydrate content in Crassostrea madrasensis and Saccostrea cucullata

\begin{tabular}{lccccc}
\hline \multicolumn{5}{c}{ Crassostrea madrasensis - Carbohydrate content } \\
\hline Regression & 1 & 166.6185 & 166.6185 & 110.7053 & Significance F \\
Residual & 10 & 15.05064 & 1.505064 & & \\
Total & 11 & 181.6692 & & & \\
& & Saccostrea cucullata - Carbohydrate content & \\
& Df & SS & MS & F & Significance F \\
Regression & 1 & 173.0951145 & 173.0951145 & 104.1024246 & $1.32167 \mathrm{E}-06$ \\
Residual & 10 & 16.62738549 & 1.662738549 & & \\
Total & 11 & 189.7225 & & & \\
\hline
\end{tabular}

Lipid: Crassostrea madrasensis in rock area, the lipid content in the whole animal were fluctuated between 5.0\%-19.9\%. The maximum lipid content value was recorded in April (19.9\%) and the minimum value was recorded in November (5.0\%). In creek are, higher percentage of lipid content was recorded (16.6\%) during April and the lower percentage of lipid content values was recorded (4.3\%) during November. In whole animal, lower values were observed during Monsoon and the higher values were observed during summer (Fig 4). In Saccostrea cucullata in rock area, the lipid content in the whole animal were fluctuated between $5.6 \%$ to $18.8 \%$. The maximum water value was recorded in May $(18.8 \%)$ and the minimum valve was recorded in December (5.6\%). In creek area, higher percentage of lipid content was recorded (17.6\%), during May and the lower percentage of lipid content values was recorded $(4.0 \%)$ during November. In whole animal, lower values were observed during monsoon and the higher values were observed during summer. In the present study, statistical analysis of the biochemical composition of the tissue sample of the oyster revealed positive correlation in both species of oyster Crassostrea madrasensis and Saccostrea 
Sustainability, Agri, Food and Environmental Research, (ISSN: 0719-3726), 9(3), 2021: 347-368

http://dx.doi.org/10.7770/safer-V0N0-art2316

cucullata. The strong Positive Correlation were observed in between the two stations and the highest value of protein, carbohydrate and lipids were observed in Crassostrea madrasensis I and II when it compare to Saccostrea cucullata(Fig. 5 and 6; Tables 7 and 8).

Table.7. Regression Analysis of Lipid content in Crassostrea madrasensis

\begin{tabular}{cccccc}
\hline Category & $\mathrm{n}$ & $\mathrm{a}$ & $\mathrm{b}$ & $\mathrm{r}$ & $\mathrm{P}$ \\
\hline Crassostrea madrasensis & 12 & $1.025 \pm 0.5341$ & $0.7760 \pm 0.04704$ & 0.98212 & $<0.0001$ \\
Saccostrea cucullata & 12 & $-1.187 \pm 0.7887$ & $1.007 \pm 0.06822$ & 0.977794 & $<0.0001$ \\
\hline
\end{tabular}

Table.8. Analysis of Variance - Lipid content of Crassostrea madrasensis and Saccostrea cucullata

\begin{tabular}{lccccc}
\hline \multicolumn{5}{c}{ Crassostrea } & madrasensis - Lipid content \\
& df & SS & MS & F & Significance F \\
Regression & 1 & 119.6729818 & 119.6729818 & 272.1684922 & $1.3966 \mathrm{E}-08$ \\
Residual & 10 & 4.397018215 & 0.439701821 & & \\
Total & 11 & 124.07 & & & \\
& & Saccostrea cucullata - Lipid content & Significance F \\
& df & SS & MS & F & \\
Regression & 1 & 213.5015 & 213.5015 & 217.6877 & \\
Residual & 10 & 9.807695 & 0.98077 & & \\
Total & 11 & 223.3092 & & & \\
\hline
\end{tabular}


Sustainability, Agri, Food and Environmental Research, (ISSN: 0719-3726), 9(3), 2021: 347-368 http://dx.doi.org/10.7770/safer-V0N0-art2316

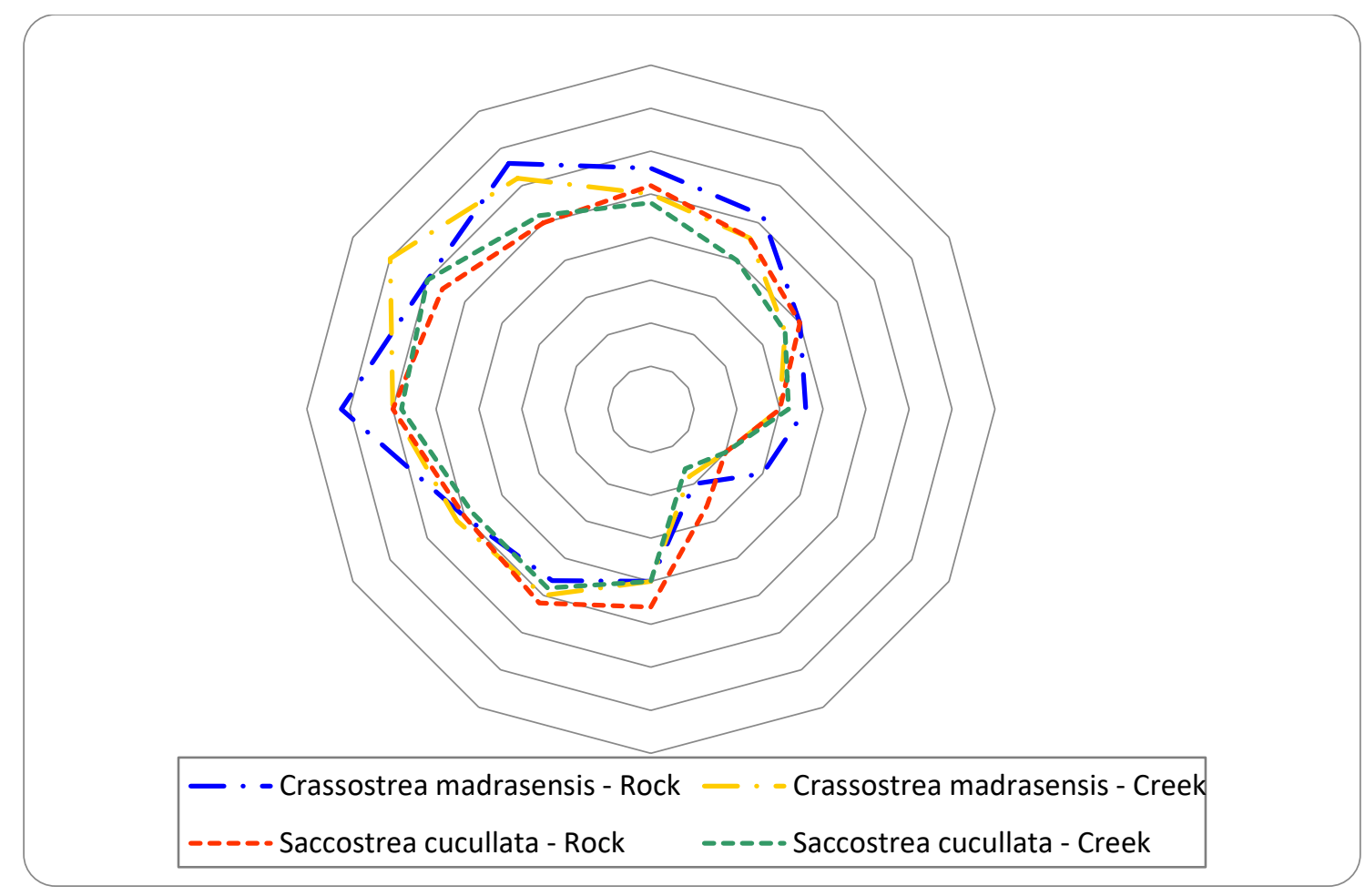

Fig.3. Carbohydrates of Crassostrea madrasensis and Saccostrea cucullata

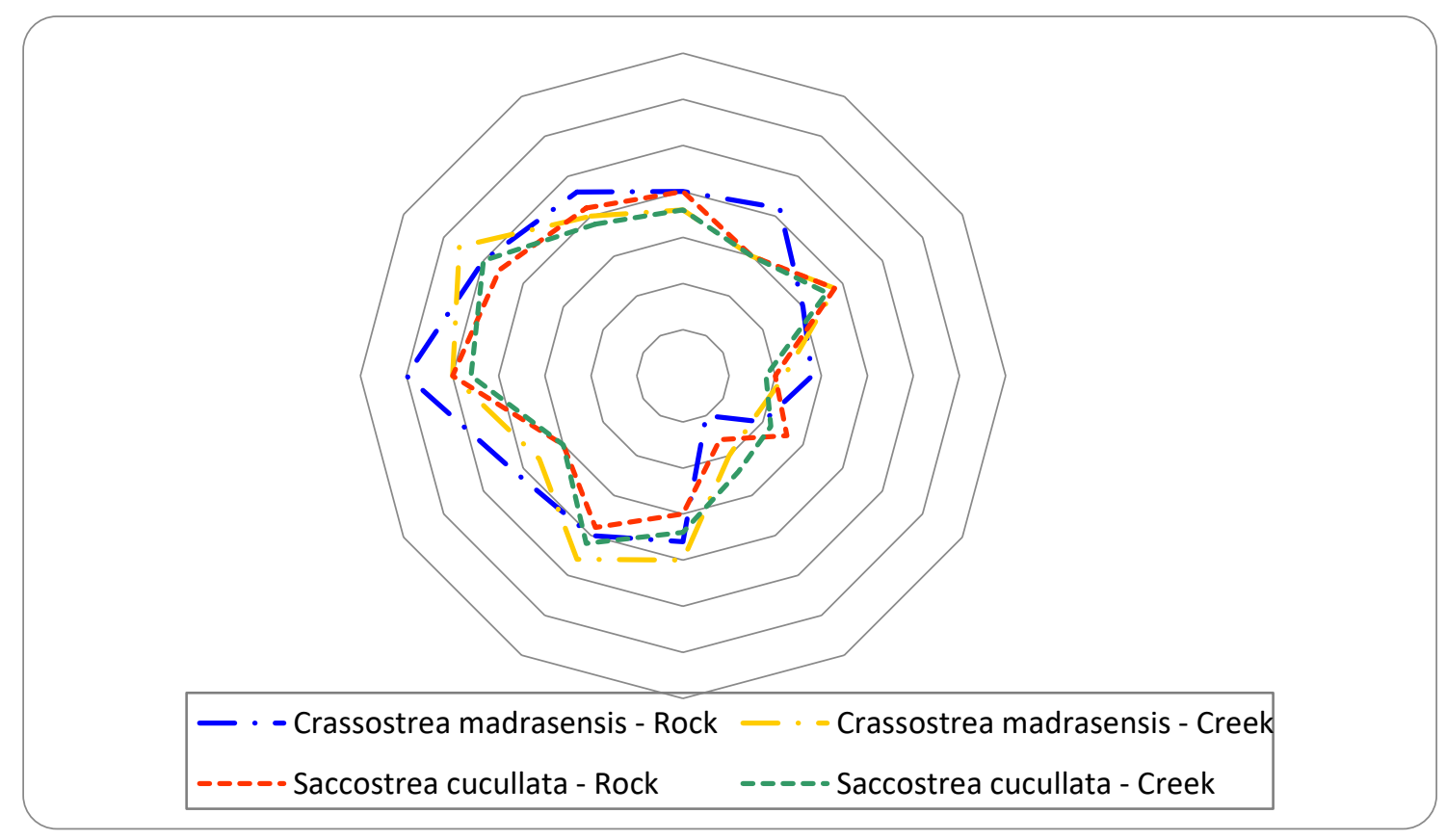

Fig.4. Lipid of Crassostrea madrasensis and Saccostrea cucullata 
Sustainability, Agri, Food and Environmental Research, (ISSN: 0719-3726), 9(3), 2021: 347-368 http://dx.doi.org/10.7770/safer-V0N0-art2316

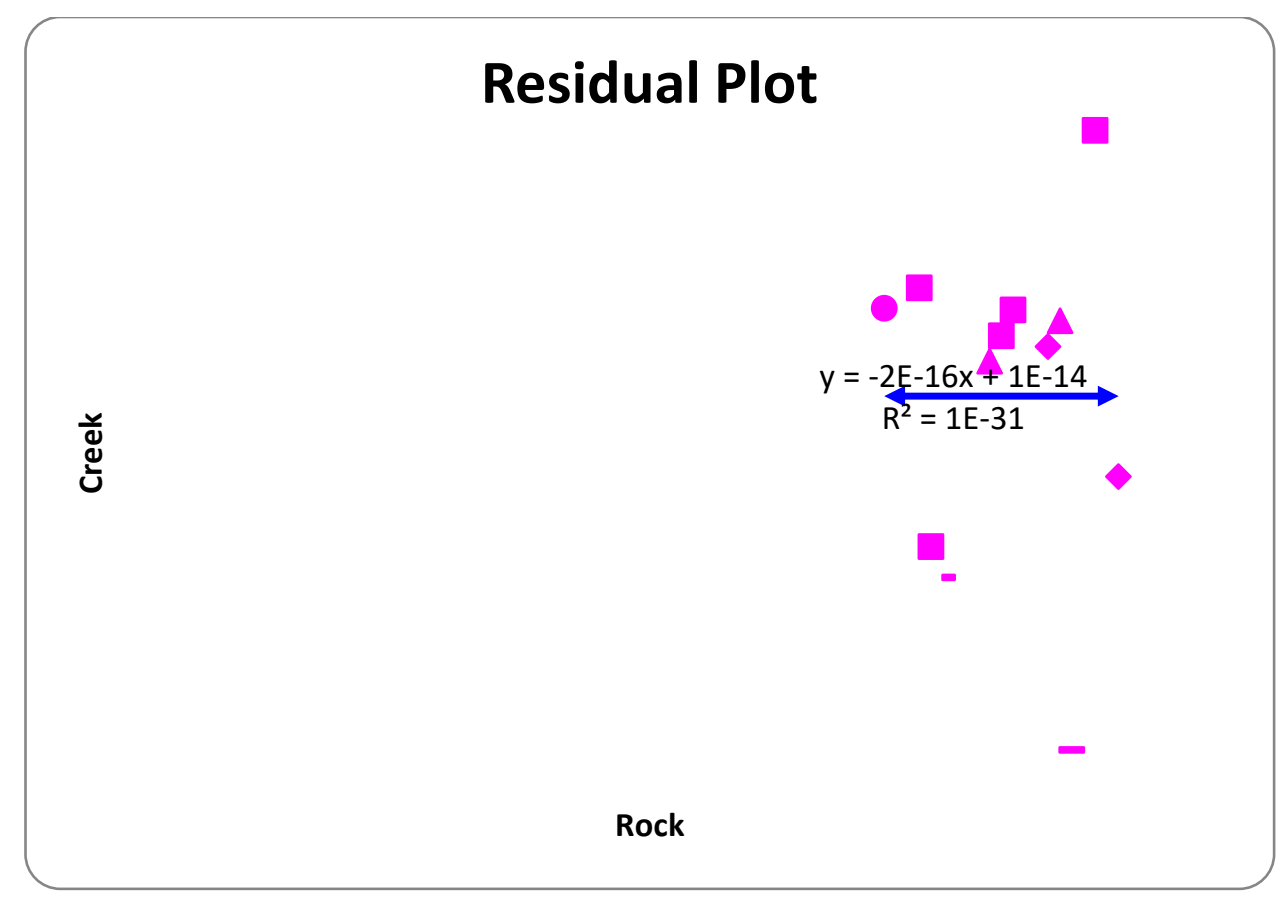

Fig. 4. Crassostrea madrasensis (Moisture content)

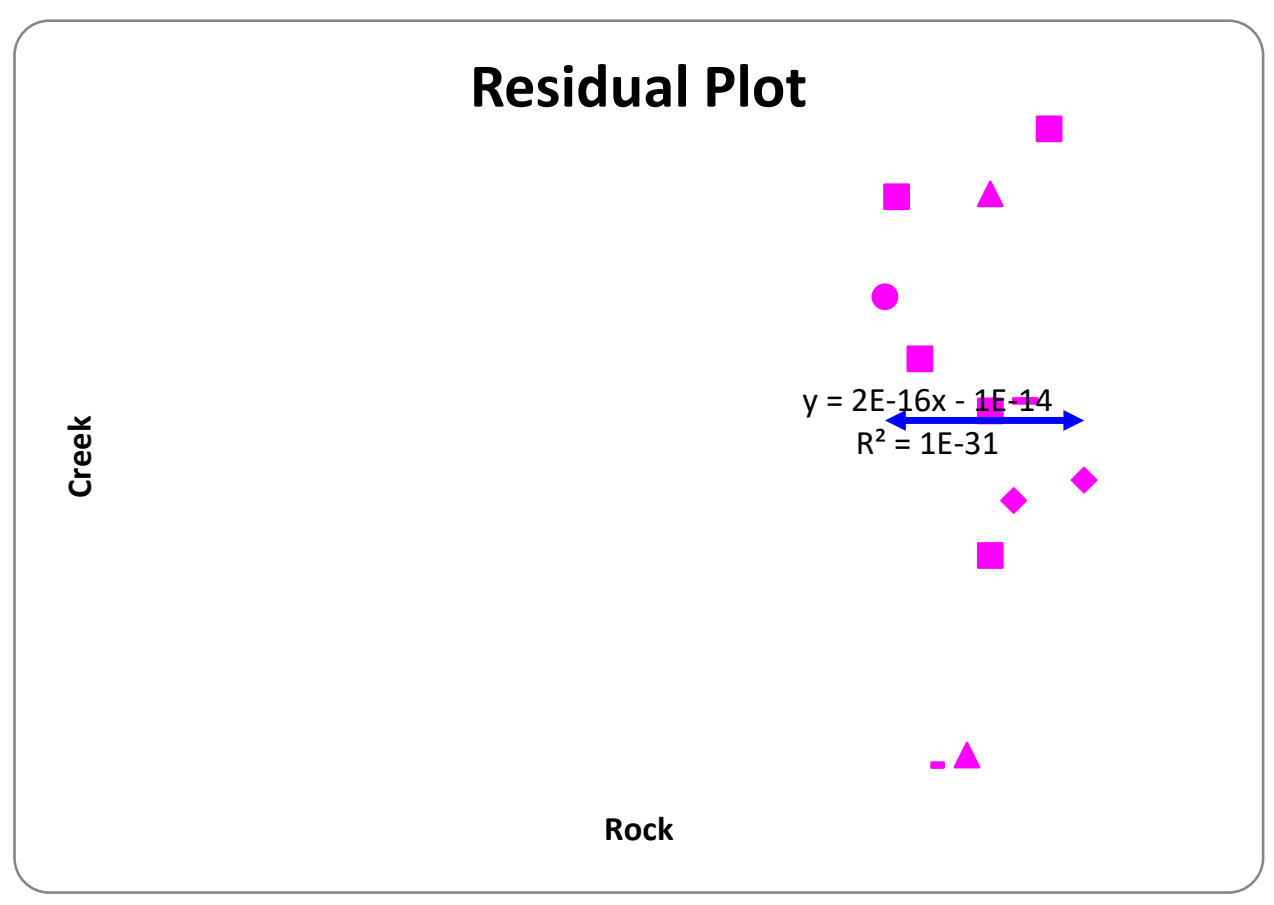

Fig.5. Saccostrea cucullata (Moisture content) 
Sustainability, Agri, Food and Environmental Research, (ISSN: 0719-3726), 9(3), 2021: 347-368 http://dx.doi.org/10.7770/safer-V0N0-art2316

\section{DISCUSSION}

Giese et al., (1958) found that in vertebrate transfer of reserve nutrient from the storage sites to gonadal synthetic centers during gametogenesis. Giese (1969) Stated that the biochemical levels varied considerably at different times during the year and the variations in protein level from month to month did not show any relation to the reproductive season in Tivela stultorum and may depend upon the difference in nutrients conditions. Ansell (1974, a, b) recorded a decrease in lipid and protein nitrogen levels during spawning period in Abra alba, Chalmysseptem radiata and Nucula sulcata. Definite changes in the biochemical constituents in clams were demonstrated by Balasubrahmanian and Natarajan (1988a) in Meretrix casta, George John (1980) in Anadara rhombae, Jayabal (1984) and Jayabal \& Kalyani, (1986) in Katelysia opima. A very good relationship between the maturation and spawning of the clams with biochemical constituents was evident.

In the present study, the water contents of the tissue in Crassostrea madrasensis and Saccostrea cucullata varied from $71 \%$ to $90 \%$. The higher percentage of water content was recorded during monsoon and lower percentage of water content was recorded in summer. These variations could be attributed to the salinity concentrations around oyster beds (Galstoff, 1964; Nagabhushanam and Bidarkar, 1978). During unfavorable conditions of salinity (higher or lower concentrations), molluscs, particularly oysters, might lose salts and gain water into their tissue when salinity reduces. During monsoon, salinity of the water drops down, leading water to enter into the body tissue increasing water contents in their body. During summer, these contents were relatively low in the tissue due to higher of salinity in ambient water. The above views could be further strengthened as low water contents were reported in bivalves during summer (Parulekar et al., 1982; Rivonkar and Parulekar, 1995). Mussels develop an appropriate compensatory mechanism to counteract the increasing salt content in the surrounding environment during summer season (Parulekar et al., 1982). It has been reported that the water contents in Indian bivalve increased after their spawning period (Venkataraman and Chari, 1951; Durve and Bal, 1961; Saraswathy and Nair, 1969). Stephen (1980b) suggested that this increase is probably exaggerated by the simultaneous decrease in the salinity of the water column.

The protein values were higher whenever adequate food was available to the surroundings. During summer season, higher values of proteins in Crassostrea madrasensis and Saccostrea cucullata could be attributed to richness of POC in ambience. Protein contents have been reported to increase during pre-spawning season (Rivonkar, 1991), which could be a mechanism for storage of reserve to meet the spawning requirements. The richness of 
Sustainability, Agri, Food and Environmental Research, (ISSN: 0719-3726), 9(3), 2021: 347-368 http://dx.doi.org/10.7770/safer-V0N0-art2316

protein in oyster was also been related to the period of maximum ripeness during May and July (Dridi et al., 2007), as well as attributed to the better metabolic conditions prevailed in the ecosystem (Qasim et al., 1977). The lowest value of protein in monsoon might be due to poor POC contents in the surroundings. The low protein contents values could also be attributed to spawning. Durve and Bal (1961) and Stephen (1980a) indicated that Crassostrea madrasensis has a well defined semi-annual breeding pattern. The major spawning activity occurs during the period from October to December. Decrease in protein contents during postspawning period could be an indication of the utilization of energy during active spawning period was contributed by protein (Galstoff, 1964; Wafar et al., 1976; Nagabhushanam and Mane, 1978; Rivonkar and Parulekar, 1995). Proteins serve as an energy reserve during the gametogensis process (Gabbott and Bayne, 1973; Ruiz et al., 1993). Nagabhushanam and Bidarkar (1978) found that protein contents of Crassostrea madrasensis were higher during pre and post-monsoon seasons, and lower values during the monsoon months. In the present study, the protein content in both species of Crassostrea madrasensis and Saccostrea cucullata showed higher values when compare to carbohydrate and lipid. The higher value of protein were observed during summer could be due to intense proliferation of gonad and in lower values were observed during monsoon may be due to spawning activity. Another peak value in August coincided with secondary peak of breeding activity and the low values in subsequent month due to spawning. Nagabushanam and Deshmukh (1974) reported that the variation in the protein level of body components of Meretrix meretrix did not show any relation to the reproductive cycle but the fat content decreased in gonad during spawning.

In the present study, carbohydrate values were high in both species Crassostrea madrasensis and Saccostrea cucullata the carbohydrate content was high during summer and low in monsoon. High carbohydrate value observed in summer could be due to intense proliferation of gonad, but were very low, when the gonad was ripe and in monsoon the low protein value may be due to spawning activity. Giese (1969) observed that in Tivela stultorum the valves of carbohydrate were high in gonad during proliferation stages. He reported that carbohydrate may act as a storage material in Tivela stultorum. Oysters have been reported to be rich in glycogen during the period of monsoon (Stephen, 1980b). Nagabhushanam and Bidarkar (1978) observed highest contents of glycogen in Crassostrea cucullata in the months of April - May and lowest during December. High carbohydrate values could be attributed to intense breeding and reproduction activities as reported in case of Crassostrea gryphoides and Meretrix meretrix (Durve and Bal, 1961; Nagabushanam and Deshmukh, 1974; Balasubrahmanyan 1984; Balasubrahmanyan and Natarajan, 1988a). On the other hand, Páez-Osuna et al., (1993) reported a decline in carbohydrate contents in both Crassostrea 
Sustainability, Agri, Food and Environmental Research, (ISSN: 0719-3726), 9(3), 2021: 347-368 http://dx.doi.org/10.7770/safer-V0N0-art2316

corteziensis (Hertlein) and Crassostrea iridescens (Hanley) during the stage of gametogensis. Glycogen has been considered to be the principal energy reserve of adult marine bivalves, especially under nutrient stress (Beninger and Lucas, 1984). It has long been known that molluscs contain a large amount of glycogen and annual cycle in oysters has been studied (Galstoff, 1964; Robert et al., 1993). During summer, carbohydrate reserves build-up in the tissue (William, 1969). Carbohydrate serves as an index of high glycogen metabolism and a bio indicator during the period of environmental stress (Parulekar et al., 1982 and Patrick et al., 2006). During spawning season, energy requirements are met by proteins and lipids to a greater extent as compared to carbohydrates (Rivonkar, 1991). Some of the glycogen gets converted into lipid and forms an energy reserve for the larvae (Quayle and Newkirk, 1989). The major biochemical constituents have been found to be stored during summer and premonsoon season for subsequent utilization of these resources during monsoon for body maintenance (Mohan and Kalyani, 1989a,b). Generally, these constituents play an important role as a gametogensis fuel and support the basic metabolic maintenance cost under the stress of food shortage (Dridi et al., 2007).

In the present study, high lipid content of Crassostrea madrasensis and Saccostrea cucullate were recorded during summer and low during monsoon season. High lipid values were observed in summer may be due to maturity and the low value may be due to spawning activity. George John (1980) suggested that digestive gland may be considered as a storage organ of lipid in Andara rhombea from velar estuary. Similar observations were also made on Chlamys septemradiata (Ansell,1947b), Tivela stultorum (Giese,1969) and Chlamys opercularis (Taylor and Venn,1979). The increase in fat content during the period of gonad development was reported by Venkataraman and Chari (1951) in Meretix meretrix and Joshi and Bal (1965) in Katelysia marmorata. The higher values of lipids in the tissue during summer could also be attributed to the higher concentrations of POC in waters influencing oyster beds and may be due to the increase in feeding efficiency (Rivonkar, 1991). These results were very close to the earlier observations on Crassostrea madrasensis by Nagabhushanam and Bidarkar (1978). Widdow and Bayne (1971) and Bayne (1973) stated that the presence of large quantum of planktons in the water column allows the accumulation of lipid as well as carbohydrate reserves. Lowest levels of lipid contents were observed in the tissue samples during monsoon were found to be consistent with low contents of POC (Widdows and Bayne, 1971; Rivonkar and Parulekar, 1995). The lower levels of lipids in the samples could also be attributed to the utilization of lipid reserves for building-up of tissue material (Rivonkar, 1991). Decrease in fat contents could also be attributed to initiation of gametogenesis and for development of gametes (Qasim et al., 1977; Zandee et al., 1980). 
Sustainability, Agri, Food and Environmental Research, (ISSN: 0719-3726), 9(3), 2021: 347-368 http://dx.doi.org/10.7770/safer-V0N0-art2316

Decrease of lipids and proteins during winter was reported in temperate species, i.e. Crassostrea corteziensis (Hertlein) by Páez-Osuna et al., (1993). The fat contents in Crassostrea madrasensis were reported to be low in July and have been attributed to the growth and maturation of gonads of the oyster (Venkataraman and Chari, 1951).The environmental conditions appear to influence the metabolic level and reproduction cycle within the oyster population (Stephen, 1980a; 1980b; Gabbott, 1983). The reduction in biochemical contents of Crassostrea madrasensis could be related to unfavorable temperature, salinity and other abiotic and biotic environmental conditions prevailing at that time. Negative environmental and nutritive stress adversely influences the biochemical composition in marine organisms (Widdows and Bayne, 1971; Bayne, 1973; Gabbott and Bayne, 1973). It may be concluded that, the oyster Crassostrea madrasensis and Saccostrea cucullata associated with mangrove habitat showed seasonal variations in biochemical composition. The present study indicates that major biochemical constituents in oyster Crassostrea madrasensis and Saccostrea cucullate are significantly influenced by environment condition such as quantity of food available, temperature and salinity. The high contents of lipids, proteins, carbohydrates, and water content values, during summer are indicating this season as the best for harvesting this particular oyster species. In the present study, statistical analysis of the biochemical composition of the tissue sample of the oyster revealed positive correlation in both species of oyster Crassostrea madrasensis and Saccostrea cucullata. The strong Positive Correlation were observed in between the two stations and the highest value of protein, carbohydrate and lipids were observed in Crassostrea madrasensis rockand creek when it compares to Saccostrea cucullata.

\section{REFERENCES}

Albentosa M. J, J. B. Kjaer and C. J. Nicol. 2003. Strain and age differences in behaviour, fear response and pecking tendency in laying hens. Br. Poult. Sci. 44:333-344.

Albentosaa, M., M.J.Fernández-Reirizb., U.Labartab and A. Pérez-Camachoc. 2007. Response of two species of clams, Ruditapesdecussatus and Venerupispullastra, to starvation: Physiological and biochemical parameters. Comparative Biochemistry and Physiology Part B: Biochemistry and Molecular Biology. Volume 146, Issue 2, Pages 241-249.

Ansell, A.D. 1974 a. Seasonal changes in biochemical composition of the bivalve Abra alba from the Clyde Sea area. Mar.Biol., 25:13-20. 
Sustainability, Agri, Food and Environmental Research, (ISSN: 0719-3726), 9(3), 2021: 347-368 http://dx.doi.org/10.7770/safer-V0N0-art2316

Ansell, A. D. 1974 b. Seasonal changes in biochemical composition of the bivalve Chlamys septemradiata from the Clyde Sea area.Ibid., 25:85-99.

Balasubrahmanyan, K. 1984. Studies on Meretrix casta (Mollusca: Bivalvia: Veneridae) from the Vellar estury, Portonovo. Ph.D.Thesis, Annamalai University, India, 135pp.

Balasubrahmanyan, K and Naatarajan, R.1988a. Seasonal Variations in the Biochemical Composition of Meretrix casta (Chemnitz) Occurring in Vellar Estuary; CMFRI Bulletin; 42(1): 184-188.

Bayne, B.L.1973. Physiological Changes in Mytilus edulis L. Induced by Temperature and Nutritive Stress; Journal of the Marine Biological Association of the United Kingdom; 53: $39-58$.

Bayne, B.L.1976. Aspects of reproduction in bivalve molluscs. In: Wiley M. (ed) estuarine processes, Vol. I, Uses. Stresses and adaptation to the estuary. Academic Press, New York, p. 432448.

Beninger,P. G. and Lucas,A. 1984. Seasonal Variations in Condition, Reproductive Activity and Gross Biochemical Composition of Two Species of Adult Clam Reared in a Common Habitat: Tapes decussatus L. (Feffreys) and Tapes philippinarum (Adams \& Reeve); Journal of Experimental Marine Biology and Ecology; 79: 19-37.

Beninger,P.G.1982. Etude biochimique compareded euz populations de bivalves Ruditapesdecussatuset and Rudita pesphilippinarum. Thèsed'Etat: Université de Brest, 193 pp.

Bressan, M and M.G.Martin.1985. Seasonal variations in biochemical composition andcondition index of cultured mussels (Mytilus galloprovincialis) in the Lagoon of Venice (North Adriatic). Aquaculture, 48, 13-21.

Bricelj, VM., Epp, J and Maloufre. 1987. Intraspecific variation in reproductive and somatic growth cycles of bay scallops Argopecten irradians. Mar Ecol Prog Ser 36:123-137.

De Zwaan A and D.I.Zandee. 1984. Body distribution and seasonal changes in glycogen content of the common sea mussel Mytilusedulis. Comp. Biochem. Physiol. A 43, 5358. 
Sustainability, Agri, Food and Environmental Research, (ISSN: 0719-3726), 9(3), 2021: 347-368 http://dx.doi.org/10.7770/safer-V0N0-art2316

Dridi,S., Romdhane, M.S and Elcafsi,M.2007.Seasonal Variation in Weight and Biochemical Composition of the Pacific Oyster, Crassostrea gigas in Relation to the Gametogenic Cycle and Environmental Conditions of the Bizert Lagoon, Tunisia; Aquaculture; 263: 238-248.

Durve, V.S and Bal, D.V.1961. Studies on the Chemical Composition of the Oyster, Crassostrea gryphoides (Schlotheim); Journal of the Zoological Society of India; 13(1): 70-77.

Folch, J., Lees M and G.H.Sloane.1957. A Simple Method for the Isolation and Purifications of Total Lipids from Animal Tissues; Journal of Biological Chemistry; 226: 497-509.

Gabbott, P. A. and Bayne, B. L. 1973. Biochemical Effects of Temperature and Nutritive Stress on Mytilus edulis L.; Journal of the Marine Biological Association of the United Kingdom; 53: 269-286.

Gabbott, P. A. 1983. Development and Seasonal metabolic Activities in Marine Molluscs; [In: The Mollusca, Vol. 2: Environmental Biochemistry and Physiology; (Ed.): Hochachka, P. W.]; AcademicPress, New York; pp. 165-217.

Galstoff, P. S. 1964. The American Oysters Crassostrea virginica Gmelin; U.S. Fish and Wildlife Service Fishery Bulletin; 64: 1-480. Ganapati, P. N and Rao M. L. V., 1959.

Ganapati, P. N and Rao M. L. V., 1959. Incidence of marine borers in the mangrove of Godavari estuary. Curr Sci 28(8):332.

George John. 1980. Studies on Anadara rhombea (Born) (Mollusca: Bivalvia: Arcidae) from Portnovo coastal waters. Ph.D., Thesis, Annamalai University, India. 190 pp.

Giese, A.C., L. Green field., H. Huang., A. Farmanfarmaian., R. Boolootian and R. Lasker. 1958. Organic productivity in the reproductive cycle of the purple Sea Urchin. Biol. Bull. (Woods Hole) 116 (1): 49 - 58.

Giese, A. C. 1969. A new approach to the biochemical composition of the mollusc body. Oceanogr. Mar. Biol. Ann. Rev., 7: 175-229.

Holland, D.L. 1978. Lipid reserves and energy metabolism in the larvae of benthic marine invertebrates. In: Malins, D.C., Sargent, J.R. (Eds), Biochemical and Biophysical Perspectives in Marine Biology, vol.4. Academic Press, New York, pp. 85-123. 
Sustainability, Agri, Food and Environmental Research, (ISSN: 0719-3726), 9(3), 2021: 347-368 http://dx.doi.org/10.7770/safer-V0N0-art2316

Jayabal, R. 1984. Studies on Meretrix meretrix, (Linnaeus) (Mollusca: Bivalvia: Veneridae) from Portonovo waters. Ph.D. Thesis, Annamalai University, India, 110 pp.

Jayabal, R and Kalyani, M. 1986. Biochemical Studies in the hard clam, Meretrix meretrix (L.) from Vellar estuary, East Coast of India. Indian J.Mar. Sci., 15: 63-64.

Joshi, M. C and D.V.Bal.1965. Observations on the chemical composition of the clam Katelysia marmorata (Lamarck). J. Zoo, Soc. India, 17: 108-11 3.

Kang, J.H., Aasi, D and Katayama, Y.2007. Bisphenol A in the aquatic environment and its endocrine-disruptive effects on aquatic organisms. Crit. Rev. Toxicol. 37, 607-625.

Kang, C.K., Park, M.S., Lee, P.Y., Choi, W.J and Lee, W.C., 2000. Seasonal variations in condition, reproductive activity, and biochemical composition of the Pacific oyster, Crassostrea gigas (Thunberg), in suspended culture in two coastal bays of Korea. J. Shellfish Res. 19, 771-778.

Kumari, L. K and Nair, V. R. 1988. Seasonal Variations in the Biochemical Composition of the Clam Tellina angulata from Bombay; Journal of the Indian Fisheries Association; 18: 449-458.

Martin, M. Hanczyc, Shelly M. Fujikawa, Jack W. Szostak. 2003. Experimental Models of Primitive Cellular Compartments: Encapsulation, Growth, and Division. Science Vol 302- 24.

Mohan, D and Kalyani, M. 1989. Seasonal Variations in Biochemical Composition of Green Mussel Perna viridis (Linnaeus); Mahasagar Bulletin of the National Institute of Oceanography; 22(3): 113-120.

Nagabhushanam, R and Bidarkar, D. S. 1978. Studies on Seasonal Changes in the Biochemical Constituents of the Oyster Crassostrea cucullata; Indian Journal of Fisheries; 25(1\&2): 156-164.

Nagabhushanam, R and Mane, U. H. 1978. Seasonal variations in the biochemical composition of Mytilus viridis at Ratnagiri, on west coast of India. Hydrobiologia, 57: 69-72.

Navarro, E., Iglesias, J.I.P and Larranaga, A. 1989. Interannual variation in the reproductive cycle and biochemical composition of the cockle Cerastoderma edule from Mundaca Estuary (Biscay, North Spain). Mar. Biol. 101, 503-511. 
Sustainability, Agri, Food and Environmental Research, (ISSN: 0719-3726), 9(3), 2021: 347-368 http://dx.doi.org/10.7770/safer-V0N0-art2316

Newell, R.I.E. 1988. Ecological changes in Chesapeake Bay: Are they the result of overharvesting the American oyster, Crassostrea virginica. In Understanding the Estuary: Aduances in Chesapeake Bay Research, Publication 129, M.P. Lynch and E.C.Krome, Eds. Baltimore, MD: Chesapeake Research Consortium.

Ojea, J., A.J. Pazos, D. Martinez, S. Novoa, J.L. Sanchez, and M. Abad. 2004. Seasonal variation in weight and biochemical composition of the tissues of Ruditapes decussates in relation to the gametogenic cycle. Aquaculture 238:451- 468.

Páez-Osuna, F.; Zazueta-Padilla, M. and Osuna-López, J. I. 1993. Biochemical Composition of the Oysters Crassostrea iridescens Hanley and Crassostrea corteziensis Hertlein in the Northwest Coast of Mexico:

Park, M.S., Kang, C.K and Lee, P.Y., 2001. Reproductive cycle and biochemical composition for the ark shell Scapharca broughtonii (Schrenck) in a southern coastal bay of Korea. J. Shellfish Res. 20, 177-184.

Parulekar, A. H., Dalal, S. G., Ansari, Z. A and Harkantra, S. N.1982. Environmental Physiology of Raft-Grown Mussels in Goa, India; Aquaculture; 29: 83-93.

Patrick, S., Faury, N and Goulletquer, P.2006. Seasonal Changes in Carbohydrate Metabolism and its Relationship with Summer Mortality of Pacific Oyster Crassostrea gigas (Thunbrg) in Marennes-Oléron Bay (France); Aquaculture; 252: 328-338.

Qasim, S. Z., Parulekar, A. H., Harkantra, S.N., Ansari, Z. A and Nair, A.1977. Aquaculture of Green Mussel Mytilus viridis L.: Cultivation on Ropes from Floating Rafts; Indian Journal of Marine Sciences; 6: 15-25.

Quayle, D. B and Newkirk, G. F. 1989. Farming Bivalve Molluscs: Methods for Study and Development, Advanced in World Aquaculture, Volume 1; International Development Research Centre; Canada; 294 pp.

Raymount, J.E.G., A. Austin and E. Linford, 1964. Biochemical studies on marine Zooplankton. I. Biochemical composition of Neomysis integer. J. Cons. Perm.Explor. Mer., 28: 354 $-363$.

Rivonkar, C. U. 1991. Ecology of Raft Grown Green Mussels Perna viridis L.; a Ph. D. Thesis Submitted to Goa University. 
Sustainability, Agri, Food and Environmental Research, (ISSN: 0719-3726), 9(3), 2021: 347-368 http://dx.doi.org/10.7770/safer-V0N0-art2316

Rivonkar, C. U. and Parulekar, A. H. 1995. Proximate Biochemical Composition and Caloric Potential in the Raft-Grown Green Mussel Perna viridis; Journal of Marine Biological Association of India; 37: 231-236.

Robert, R., Trut, G., Borel, M and Maurer, D.1993. Growth, Fatness and Gross Biochemical Composition of the Japanese Oyster, Crassostrea gigas, in Stanway Cylinders in the Bay of Arcachon, France; Aquaculture; 110: 249-261.

Rodhouse, P.G., Roden, C.M., Burnell, G.M., Hensey, M.P., McMahon, T., Ottway, B and Ryan, T.H., 1984. Food resource, gametogenesis and growth of Mytilus edulis on the shore and in suspended culture: Killary Harbour, Ireland. J. Mar. Biol. Ass.U.K. 513-529.

Ruiz, C., Martinez, D., Mosquera, G., Abad, M and Sánchez, J.L. 1992. Seasonal Variations in Condition, Reproductive Activity and Biochemical Composition of the Flat Oyster, Ostrea edulis, from San Cibran (Galicia, Spain); Marine Biology; 112: 67-74.

Ruiz, G. M., Hines, A. H and Posey, M. H. 1993 Shallow water as a refuge habitat for fish and crustaceans in non-vegetated estuaries: an example from Chesapeake Bay. Marine Ecology Progress Series 99, 1-16.

Salaskar, G.M and Nayak, V.N. 2011. Nutritional quality of bivalves, Crassostrea madrasensis and Perna viridis in the Kali estuary, Karnataka, India. Recent Research in Science and Technology. 3(4): $6-11$.

Saraswathy, M and Nair, N. B. 1969. Biochemical Changes in Relation to the Breeding Cycles of Nausitora hedleyi Schepman (Bivalvia: Teredinidae); Current Science; 38(7): 158160.

Sastry, A. N. 1979. Pelecypoda (excluding Ostreidae).In: Giese, A. C., Pearse, S. K. ed. Reproduction of marine invertebrates. Vol. 5. New York, Academic Press. Pp. 113-292.

Stephen, D. 1980a. The Reproduction Biology of the Indian Oyster Crassostrea madrasensis (Preston), I. Gametogenic Pattern and Salinity; Aquaculture; 21: 139-146.

Stephen, D. 1980b. The Reproduction Biology of the Indian Oyster Crassostrea madrasensis (Preston), II. Gametogenic Cycle and Biochemical Levels; Aquaculture; 21: 147-153. 
Sustainability, Agri, Food and Environmental Research, (ISSN: 0719-3726), 9(3), 2021: 347-368

http://dx.doi.org/10.7770/safer-V0N0-art2316

Taylor, A. C and Venn, T.J. 1979. Seasonal variation in weight and biochemical composition of the tissues of the queen scallop Chlamys opercularis, from the Clyde sea area. J. Mar. Biol. Ass. U. K., 59: 605-621.

Venkataraman, R and Chari, S. T. 1951. Studies on Oysters and Clams: Biochemical Variation; Indian Journal of Medical Research; 39(4): 533-541.

Wafar, M. V. M., Vijayaraghavan, S and Kumari, L. K. 1976. Seasonal Changes in the Nutritive Value of the Green Mussel, Mytilus viridis Linné; Indian Journal of Marine Sciences; 5: 252-254.

Widdows, J and Bayne, B. L. 1971. Temperature Acclimation of Mytilus edulis with Reference to its Energy Budget; Journal of the Marine Biological Association of the United Kingdom; 51: 827-843.

Williams, C.S. 1969. The Effects of Mytilicola intestinalis on the Biochemical Composition of Mussels; Journal of the Marine Biological Association of the United Kingdom; 49: 161173.

Zandee, D. I., Kluytmans, J. H and Zurburg, W. 1980. Seasonal Variation in Biochemical Composition of Mytilus edulis with Reference to Energy Metabolism and Gametogenesis; Netherlands Journal of Sea Research; 14(1): 1-29.

Received: 05 ${ }^{\text {th }}$ September 2020; Accepted: $18^{\text {th }}$ September 2020;

First distribution: 07 ${ }^{\text {th }}$ January 2021. 